\title{
Instrument Test Development Of Mathematics Skill On Elementary School
}

\author{
Sarson W. Dj. Pomalato ${ }^{1 *}$, Raoda Ismail ${ }^{2}$, Amin Otoni Harefa ${ }^{3}$, Okky Riswandha Imawan ${ }^{4}$, \\ Besse Arnawisuda Ningsi ${ }^{5}$, Dena Wulandari ${ }^{6}$
}

\author{
${ }^{1}$ Mathematics Education Study Program, Faculty of Mathematics and Natural Science, Universitas NegeriGorontalo, \\ Gorontalo, Indonesia \\ ${ }^{2}$ Mathematics Education Study Program, Faculty of Teacher Training and Education, Universitas Cenderawasih, \\ Jayapura,Indonesia \\ ${ }^{3}$ Mathematics Education Study Program, Faculty of Mathematics and Natural Science, Institut Keguruan Dan Ilmu \\ Pendidikan (IKIP) Gunungsitoli, Gunungsitoli \\ ${ }^{4}$ Primary School Teacher Education Study Program, Faculty of Teacher Training and Education, Universitas \\ Cenderawasih, Jayapura, Indonesia \\ ${ }^{5}$ Mathematics Study Program, Faculty of Mathematics and Natural Science, Universitas Pamulang, Tangerang Selatan, \\ Indonesia \\ ${ }^{6}$ Informatics Engineering Study Program,Universitas Pamulang,Tangerang Selatan, Indonesia \\ *Coresponden Author : sarson@ung.ac.id
}

Abstract--The aims of this research are producing the test instrument of mathematics skill on elementary school which is valid and reliable. The instrument test development in this research use the development model of Wilson, Oriondo and Antonio which is modified. The number of testing sample in this research is 160 of students in each class. This research result: 1) the validity index of aiken v is 0.979 in grade IV and 0.988 in grade V. The coefficient of instrument skill in class IV and V are 0.883 and 0.954 . The case indicates that the overall item is accepted and reliable to be used for measuring the development of mathematics skill of elementary school students.

Keywords: development test, characteristics of instrument, Mathematics, Elementary school

\section{INTRODUCTION}

Elementary school is an educational institution which has a function to impart the basic ability and skill for the necessity of the lesson continuity on higher level education, and to give the skill provision for students to make self-development which is suitable for their ability and interest, as well as their environment condition. The ability in counting and measuring as well as reading and writing skill in elementary school are the basic for other skills development which is higher.

For instance, National Council of Teachers of Mathematics (NCTM, 2000: 16) propose that the development of mathematics skill of students in class K-2 usually can explore the similarity and the difference on two dimensions shape, in class 3 to 5 they are able to identify the characteristics of various rectangular, in class 6 to 8 they are able to check and 
make a generalization about the characters of certain rectangular, and in class 9 to 12 they are able to develop the logic argument to confirm the notion about certain polygon. The case gives the description that the mathematics skill develops from early age to mature or the mathematics skill develops from kindergarten level to high school level.

The result of Trends in Mathematics and Science Study (TIMSS) (2012) which is followed by Indonesian students of class VIII in 2011 show that for mathematics field, Indonesia is in 38th place with the number of scores is 386 of 42 countries. This score decreases eleven points from the rating in 2007. Program for International Student Assessment (PISA), hold the survey about students' skill and educational system, where the students' skills assessed in this survey are mathematics, reading and science skill which reflect the educational system in each country. The result shows that students' mathematics skill in Indonesia was ranked 64 of 65 countries or second order from the bottom with the number of scores is 375 .

The survey result indicates that Indonesian students' mathematics skill is still low both in content dimension and cognitive dimension. The content dimension assessment on the domain: numbers, algebra, geometry, data and probability. Meanwhile, on the cognitive dimension assessment in domain: 1) knowledge, including the facts, concept and procedure which should be known by the students, 2) applying, which focus on students' skill in applying the knowledge and concept understanding to solve the problem or answering the question; 3) reasoning which focus on problem solving non-routine, complex context and taking many problem-solving steps.

Based on the report result of the research conducted by Mathematics Teacher Upgrading Development Centre Team that investigate in several elementary schools in Indonesia, reveals that 51 percent of students have difficulty in counting aspect, 50 percent of students have difficulty in concept mastery and 49 percent of students have difficulty in completing the story test (Tim PPPG Matematika, 2001: 18). In 2002, based on the research result from Mathematics Teacher Upgrading Development Centre Team reveals that in several areas in Indonesia, most of elementary students have difficulty in solving the story tests and interpret the story test into mathematics model (Tim PPPG Matematika, 2002: 71).

On the survey conducted, Indonesian team is only followed by students of class VIII or 
junior high school students, while students of class IV or elementary school students are not included in the survey. This case is necessity to be conducted a further research to assess the students' mathematics skill in class IV or in elementary school level. The assessment is crucial to be conducted in order to give the information about the development achievement of students' mathematics skill or how far students have mastered the competency that they want to reach as a result of the learning.

Until now days, there are still several problems in school relating with the quality and assessment implementation activity, especially in elementary school level. This case relates with the goal, planning, implementation, result and follow-up of assessment result both it is conducted by teacher and school. Based on the research result by Djemari Mardapi, dkk. (1999: 45) reveals that there are still many teachers that are not guided on the test grid in making question. They tend to use the question taken from books. The research conducted by Kumaidi (2005: 5-6) reveals that teacher did not make the grid first in making test question. There are many teachers that do not utilize the data from assessment result to improve the learning process. The data is only used for giving a label for students that are pass or not pass. The aims of this research are producing the test instrument of mathematics skill on elementary school which is valid and reliable.

\section{RESEARCH METHOD}

This research isresearch and development research, namely the development of mathematics skill test in elementary school. The product that will be produced from this research is a mathematicalskill test instrument in elementary school. The math skill test is used to identify the level of mathematics skill of elementary school students and measure the development of math skill of elementary school students. The product of the development of mathematics skill test for elementary school students is the instrument of mathematics skill test of elementary school students in the form of multiple choice. Instrument development criteria are limited to knowledge domains based on the 2013 curriculum. 


\section{Development Model}

Instrument development model in the form of test using modifications of the Wilson Model (2005: 18) and Order and Antonio Model (1998: 34) with the following steps: (1) initial development of the test, (2) test trial and (3) broad-scale trial. Initial development consists of: design of tests and validation by expert's judgement. After the design of the test is complete, the test is validated by expert, if any items that are not yet eligible are revised first until the test is valid in content. The instrument was tested on students in grades III, IV, and V elementary school. Based on trial, unfit items were revised and fit items were assembled as fit mathematical test. This mathematical test is ready to be used for measuring, then continued the broad-scale trial process.

\section{Development Procedure}

Determining the Test Goal

On the initial test stage, first that should be done is determining the test goal. The instrument includes summative test due to it is given the chance at the last stage of learning or final semester. So, the aim of the test is to know the students' mathematics skill in grade III, IV and V on elementary school.

\section{Determining the Competency Tested}

After the objective of the test are clear, then selected the competency which will be tested. This competency is suitable for core competency (CC) and basic competency (BC) for mathematics grades III, IV, and V elementary schools. Based on core competency and basic competency determined indicators that correspond

\section{Arranging the Test Grid}

To be able to make a good question item, it is required the test grids. A grid is a matrix containing the specification of the test items made. This grid is a reference for writing the question, so by the test grid, whoever writing the question will produce the question and the difficulty level which is relatively the same.

Writing the Item 
As stated above, the grid test has an important role in test development. The test items are made based on the grid test.

Arranging Scoring Guidance

The test can be used, if it is completed with the scoring guidance. Scoring guidance is designed to maintain the objectivity of assessment and score certainty obtained by the participant of the test.

Content Validity of the Test

After the items are compiled in the math skill test in grade III, IV, and V of Elementary School and the scoring guideline is conducted the limited trial. This limited trial was conducted with the aim to find out the readability of the test details. Limited trial results are used as the basis for revision and refinement of the items. Besides limited trial, in order to obtain good instruments, the lattice of instruments, items, and scoring guidelines that have been compiled are subsequently reviewed, and validated. The validation process, in order to meet the requirements in terms of concept, construction and language is used with expert's judgement.

\section{RESULT AND DISCUSSION}

One of the educational problems related to the quality of education is the low mastery of students toward the competence, as a result of students' inadequate assessment. The assessment system is not optimal because: (1) the quality of tests made by teachers is still inadequate, (2) the monitoring of the testing network in the area has not been conducted properly, (3) the reporting of exam results has not been optimal, and (4) the utilization of exam results has not been done optimally.

Based on the description above, this research tries to develop math skill test for elementary school students in grades IV and V. Development of mathematics skill test refers to Core Competency and Basic Competency based on curriculum 2013. The test is expected to be able to identify the level of math skill of elementary school students, measure the development of math skill of elementary school students, and compile a profile of the level of achievement of students' math skill. 


\section{Content Validity of the Instrument}

Validity is classified into three types, such as: (1) validity of content, (2) validity of criteria (criterion-related) and (3) validity of constructs (Nunnally, 1978, Allen \& Yen, 1979, Fernandes, 1984, Woolfolk \& McCane, 1984, Kerlinger, 1986, and Lawrence, 1994). This validity can be found out through the analysis of the contents of the test and empirical analysis of the test score of grain response data (Lissitz \& Samuelsen, 2007). The validity of the contents of an instrument is defined as to what extent the items in the instrument represent the components in the entire content of the object to be measured and to what extent they reflect the characteristics of behaviour to be measured (Nunnally, 1978; Fernandes, 1984).

The validity of the content is determined by using expert agreement. Expert agreement of the field of study or often referred to as a measured domain determines the level of validity of content related (Heri Retnowati). This case is caused by the measurement instruments, such as tests or questionnaires are proven valid only if the expert believes that the instrument is able to measure the mastery of the capabilities defined in the measured domain. Analysing the validity of the content uses the aiken formula.

The instrument can be stated valid if the expert believes that the instrument measure the things which will be measured. Expert judgement gives the scoring used that will be used to prove the content validity toward the number of instruments in this research. The instrument that will be validated are as follow:

Table 1. Instrument Validated

\begin{tabular}{|c|c|c|}
\hline No & Research Instrument & $\begin{array}{c}\text { Number of } \\
\text { Items }\end{array}$ \\
\hline 2 & Instrument of grade III & 40 \\
\hline 3 & Instrument of grade V & 40 \\
\hline
\end{tabular}

Table 1 is the instrument which will be validated. The instrument consists of 
instrument of grade IV and V. each instrument consists of 40 items of question. The result of validity instrument verification is described on the table below.

Table 2. Calculation Index of Aiken's V

\begin{tabular}{|c|c|c|c|}
\hline No & Instrument & $\begin{array}{c}\text { Number of } \\
\text { items }\end{array}$ & $\begin{array}{c}\text { Index Average of } \\
\text { Aiken V }\end{array}$ \\
\hline 2 & $\begin{array}{c}\text { Instrument of } \\
\text { grade III }\end{array}$ & 40 & 0.979 \\
\hline 3 & $\begin{array}{c}\text { Instrument of } \\
\text { grade V }\end{array}$ & 40 & 0.988 \\
\hline
\end{tabular}

Table 2 is an average table of calculation validity results by using Aiken's v Index in grade III and V test instruments, where each instrument consists of 40 problem items. Table 2 shows that grade III instruments have an average Aiken's v index 0.979, and grade V instruments have an average Aiken's v index of 0.988. The average of Aiken's v index in each instrument is quite high.

\section{Reliability of Instrument}

The reliability of a test is generally expressed numerically in a coefficient of $-1.00 \leq \rho \leq$ +1.00 (Retnawati, 2016). Mahrens \& Lehman (1973) stated that although there is no general agreement, it is widely accepted that for test used to make decisions on individual students should have a minimum reliability coefficient of 0.85 . The estimated reliability of the research used the Cronbach-alpha formula and was analysed with the support of the SPSS 22 program. The estimated reliability results on three instruments are presented below.

Table 3. Instrument Reliability of Grade III, IV, \& V

\begin{tabular}{|c|c|c|}
\hline Instruments & $\begin{array}{c}\text { Cronbach- } \\
\text { alpha }\end{array}$ & $\begin{array}{c}\text { Number } \\
\text { ofItems }\end{array}$ \\
\hline
\end{tabular}




\begin{tabular}{|c|c|c|}
\hline $\begin{array}{c}\text { Instrument of } \\
\text { grade IV }\end{array}$ & 0,883 & 40 \\
\hline $\begin{array}{c}\text { Instrument of } \\
\text { grade V }\end{array}$ & 0,954 & 40 \\
\hline
\end{tabular}

Table 3 is the estimation result of the reliability on the research instrument developed. This research estimates the reliability on the instrument in grade IV and V where on each instrument consists of 40 items of questions.

Table 3 explains that the number of reliability coefficient of instrument in grade IV is 0.951. the result of coefficient estimation of the reliability shows that three instruments are reliable to use in measuring the students' mathematics skill in elementary school grade IV and $\mathrm{V}$.

\section{CONCLUSION}

Based on the results of the development and discussion, the development of elementary school math skill test, the average of Aiken value for the instrument of Grade 4 is 0.979 . Based on the data, it can be stated that all items proved valid reviewed from the validity of the content. The Aiken value range for the instrument of grade 5 is 0.988 . Based on the data, it can be stated that all items proved valid reviewed from the validity of the content. Based on the results of the analysis showed that the coefficient of reliability instrument of grade 4 is 0.883 , package instrument of grade 5 is 0.954 , it is concluded that all instruments developed can be stated reliable. It shows that all items are accepted and reliable to be used to measure the development of math skill of elementary school students.

\section{REFERENCES}

[1] Allen, M. J. \& Yen, W. M. (1979). Introduction to measurement theory. Belmont, CA: Wadsworth, MC.

[2] Brennan, R.L.\& Kolen, M.J. (2004), Test equating, scaling, and linking. Iowa City: United State of America: American Council on Education and Springer Publisher

[3] Croker, L. \& Algina, J. (1986). Introduction to classical and modern test theory. New York: Holt, Rinehard and Winston Inc.

[4] Djemari Mardapi. (1999). Estimasi kesalahan pengukuran dalam bidang pendidikan dan implikasinya pada ujian nasional. Pidato Pengukuhan Guru Besar. Yogyakarta: Universitas Negeri Yogyakarta. 
[5] Fernandes, H. J. X. (1984). Evaluation of educational program. Jakarta: National Education Planning, Evaluating and Curriculum Development.

[6] Furr, R. M. \& Bacharach, V. R. (2008). Psychometrics an introduction. Thousand Oaks: Sage Publications, Ins.

[7] Hambleton, R.K., Swaminathan, H., \& Rogers, HJ. (1991). Fundamental of item response theory. Newbury Park, CA: Sage Publication Inc.

[8] Lee, O.K. (2003). Rasch Simultaneous Vertical Equating for Measuring Reading Growth. Journal of Applied Measurement, 4(1), 10-23.

[9] Mehrens, W.A. \& Lehmann, I.J. (1973). Measurement and evaluation in education and psychology. New York: Hold, Rinehart and Wiston, Inc.

[10] NCTM. (2000). Principles and standards for school mathematics. Reston, VA: NCTM, Inc.

[11] Nunnally, J. (1978). Psychometric theory (2nd ed.). New York: McGraw Hill.

[12] OECD. 2013. PISA 2012 Assessment and Analytical Framework: Mathematics, Reading, Science, Problem Solving and Financial Literacy. OECD Publishing.

[13] Retnawati, H. (2014). Membuktikan Validitas Instrumen dalam Pengukuran. Diambil dari: http://evaluation-edu.com/wp-content/uploads/2014/10/2-Validitas-heri-Retnawati-uny.pdf

[14] Retnawati, H. (2016). Validitas, Reliabilitas, \& Karakteritik Butir. Yogyakarta: Parama Publishing

[15] Sugeng. (2010). Penyetaraan vertikal model kredit parsial soal matematika SMP. Jurnal Penelitian dan Evaluasi Pendidikan, Tahun 14, No. 2. UNY.

[16] Vendramini, C.M.M. \& Silvia, M.C.R. (2011). Application of item response theory in the attitudes evaluation. Diambil tanggal 4 April 2015, dari http://www.tsg.icme11.org/document/get/492.

[17] Wagiran. (2014). Metodologi penelitian pendidikan (teori dan implementasi). Yogyakarta: Depublish.

[18] Woolfolk, A. E. \& McCune, L. N. (1984). Educational psychology for teachers. Englewood Cliffs, NJ.: Prentice Hall, In. 